\title{
Environmental support of metallurgical plant construction project in the Subarctic Mountains (Trans-Baikal Territory)
}

\author{
Nadezhda Pomazkova ${ }^{1, *}$, Marat Usmanov ${ }^{1}$, and Igor Miheev ${ }^{1}$ \\ ${ }^{1}$ Institute of Natural Resources Ecology and Cryology Siberian Branch Russian Academy of Sciences, \\ 16A, Nedorezova str., 672014, Chita, Russia
}

\begin{abstract}
The article analyzes the results of the environmental assessment of the construction site of the Udokan mining and metallurgical plant (MMP) in the Kalarsky district of the Trans-Baikal Territory. The Udokan deposit is the largest deposit in Russia with copper reserves of 20.1 million tons. The construction area is characterized by extreme natural conditions, natural complexes that are sensitive to anthropogenic impact. The results of the environmental impact assessment of the territory of the planned construction of the Udokan mining and metallurgical plant for the extraction and processing of copper are analyzed. The impact of the construction and the Udokan project on copper mining is assessed as significant. However, taking into account the observance of all technical and operational standards, it can be assessed as acceptable. Specialists of the Institute have developed and implemented a system of environmental monitoring of the impact of construction on the environment. A set of environmental measures to preserve the biodiversity of mountain subarctic ecosystems is proposed.
\end{abstract}

\section{Introduction}

In the process of mining, construction and operation of any mining and metallurgical plant, a priori significant damage is inflicted on natural complexes and their components. Therefore, each new construction of a large facility is perceived as a large-scale project to violate the ecological well-being of the territory. In this regard, high-quality and independent research to assess the impact on environmental components at all stages of work is an urgent task. In modern conditions, environmental safety is becoming a priority for residents of the development area, as well as for mining companies. New technological solutions, compliance with all environmental requirements and norms, compensation measures and participation in improving the quality of life of the population are not only legal requirements, but also a contribution to increasing the company's reputation in the global investment market. Impact business projects are a global trend of large companies investing in the development of the territory in accordance with the goals of sustainable development. These also include companies that adhere to high standards in ensuring the

\footnotetext{
*Corresponding author: naste2@yandex.ru
} 
environmental safety of their projects. In general, the system for ensuring the environmental safety of territories consists of three main blocks: a comprehensive environmental assessment of the territory; subsystem of environmental monitoring; subsystem of management decisions. The relationship between these systems at all levels will be the key to rational environmental management, improving the quality of life of the population.

\section{Materials and methods}

The Udokan copper deposit is the largest copper deposit in Russia and one of the largest in the world. The deposit is located in the Kalarsky district of the Trans-Baikal Territory, 30 $\mathrm{km}$ from the station «New Chara» (Baikal-Amur Mainline). The annual productivity of the 1st stage of the Udokan mining and metallurgical plant is 12 million tons of ore per year. The implementation of the project will fully meet the domestic needs of the Russian economy and export copper, primarily to the countries of South-East Asia: China, South Korea, Japan. For the processing of ores from the Udokan deposit, a flotationhydrometallurgical technological scheme was adopted. Products of MMP Udokan: cathode copper and sulphide concentrate.

The Institute of Natural Resources, Ecology and Cryology of the Russian Academy of Science Siberian bureau (INREC SB RAS) conducts engineering and environmental surveys and monitoring work at many deposits and mining facilities in Transbaikalia. One of which is the Udokan copper deposit, which has been studied at the Institute since the 1970s. The Institute's specialists studied a wide range of problems related to various aspects of the development of this field: from socio-economic to engineering and environmental [ 1 ; $2 ; 3]$. Then, due to the various reasons, including changed socio-economic conditions, project was frozen for several ten years. Since 2011, the Institute has been carrying out environmental engineering and monitoring work at the field (license No. СРО-И-02414012010-00169).

In this work, we will focus only on the direction of environmental support of this project related to nature conservation issues.

\section{Results and Discussion}

\subsection{Comprehensive assessment of the territory}

In 2017-2018, the Baikal Mining Company (since January 2021, Udokan Copper) began preparing design documentation for all the main complexes of MMP Udokan: mining, technological, infrastructure, energy, shift camp, water intake, road. All design solutions were confirmed by the engineering survey program. Specialists of INREC SB RAS prepared special sections of the project documentation - "Engineering and environmental surveys. Technical Report" and "Environmental Impact Assessment (EIA)".

Natural and climatic conditions remain one of the key factors that must be taken into account in the construction and development of the field. Highly dissected mountainous terrain, harsh climate and permafrost caused the high sensitivity of inland mountain ecosystems to anthropogenic impact, as well as the need for special engineering decisions during the construction of mining and metallurgical facilities.

It was noted that at all stages of the project implementation, large volumes of waste will be generated associated with the removal of overburden during the development of crankcases, with the operation of the concentration plant and the hydrometallurgical workshop (tailing dump). 
The assessment identified the following impacts:

Table 1. Use of land resources for the placement of the main objects of the planned activity (mining complex, technological complex, infrastructure complex).

\begin{tabular}{|c|c|}
\hline $\begin{array}{c}\text { Direct and indirect } \\
\text { impacts }\end{array}$ & Assessment of changes \\
\hline $\begin{array}{c}\text { Withdrawal from } \\
\text { economic use and } \\
\text { circulation of forest } \\
\text { lands }\end{array}$ & $\begin{array}{c}\text { Forest plantations are characterized by a very low bonitet and do not } \\
\text { belong to commercial forests. The withdrawal of unproductive } \\
\text { forest lands with an area of up to 2,000 hectares will not lead to } \\
\text { significant changes in the structure of land use in the Kalarsky } \\
\text { region and will not have an impact on traditional nature } \\
\text { management due to the lack of commercial forestry in areas of } \\
\text { traditional nature use. }\end{array}$ \\
\hline $\begin{array}{c}\text { Loss of biotopes } \\
\text { (habitats of certain } \\
\text { species of flora and } \\
\text { fauna) }\end{array}$ & $\begin{array}{c}\text { The territory of development of the MMP "Udokan" is typical for } \\
\text { the region as a whole, the withdrawn biotopes are not critical } \\
\text { habitats, negative consequences are not predicted. } \\
\text { Most of the work is planned to be carried out in the winter, which } \\
\text { minimizes the impact on soil and shrub vegetation. } \\
\text { It is planned to withdraw the sections of watercourses, with the } \\
\text { absence of ichthyofauna and not essential for its reproduction }\end{array}$ \\
\hline $\begin{array}{c}\text { Increase in the area } \\
\text { occupied by } \\
\text { technogenic } \\
\text { landscapes }\end{array}$ & $\begin{array}{c}\text { Areas previously disturbed and / or areas of development of kurums } \\
\text { are subject to development, the negative consequences are minimal } \\
\text { due to the absence of any significant withdrawal of areas of soil } \\
\text { cover }\end{array}$ \\
\hline
\end{tabular}

Table 2. Impact on natural ecological systems (landscapes) and their components.

\begin{tabular}{|c|c|}
\hline $\begin{array}{c}\text { Direct and indirect } \\
\text { impacts }\end{array}$ & Assessment of changes \\
\hline $\begin{array}{c}\text { Loss and } \\
\text { fragmentation of } \\
\text { biotopes (habitats of } \\
\text { certain species of } \\
\text { flora and fauna) }\end{array}$ & $\begin{array}{c}\text { The territory of development of MMP "Udokan" is typical for the } \\
\text { region as a whole, the withdrawn biotopes are not critical habitats. } \\
\text { Biotopes with a lichen cover are under the greatest threat due to } \\
\text { their high sensitivity to pollution. It is planned to withdraw the } \\
\text { sections of watercourses, with the absence of ichthyofauna and not } \\
\text { essential for its reproduction }\end{array}$ \\
\hline $\begin{array}{c}\text { Impact on the } \\
\text { migration of objects } \\
\text { of the terrestrial } \\
\text { animal world }\end{array}$ & $\begin{array}{c}\text { The objects of the MMC "Udokan" do not affect the migration } \\
\text { routes of objects of the terrestrial animal world, indirect impacts on } \\
\text { the migration routes of the avifauna are possible }\end{array}$ \\
\hline $\begin{array}{c}\text { Changes in the } \\
\text { biotopic conditions } \\
\text { of aquatic } \\
\text { organisms; } \\
\text { indirect impacts on } \\
\text { biotopes of } \\
\text { watercourses located } \\
\text { downstream }\end{array}$ & $\begin{array}{c}\text { Design solutions (minimization of the duration of the construction } \\
\text { period, mainly the winter period of construction work, collection, } \\
\text { disposal and treatment of all types of wastewater). Taking into } \\
\text { account the effect of the implementation of environmental design } \\
\text { measures, in the construction area of the Udokan MMP, no } \\
\text { deterioration of the state of water bodies is predicted in comparison } \\
\text { with the formed indicators of the natural background }\end{array}$ \\
\hline
\end{tabular}




\begin{tabular}{|c|c|}
\hline $\begin{array}{l}\text { Loss of rare and } \\
\text { protected plant and } \\
\text { animal species }\end{array}$ & $\begin{array}{l}\text { Rare plants from the current International Union for Conservation } \\
\text { of Nature and Natural Resources (IUCN) list, as well as plant } \\
\text { species from the Convention on International Trade in Endangered } \\
\text { Species of Wild Fauna and Flora (CITES) list, have not been found. } \\
\text { On the territory of the MMP construction, } 9 \text { rare species of higher } \\
\text { plants, } 5 \text { species of lichens included in the Red Book of the Trans- } \\
\text { Baikal Territory have been identified. Since the area of the deposit } \\
\text { is geobotanically typical for the region as a whole, the discovered } \\
\text { habitats are not their only habitats. } \\
\text { The alpine part of the Udokan ridge, in the area of which a } \\
\text { significant part of the territory of the MMP Udokan is located, is } \\
\text { characterized by a poor animal population. } 1 \text { species of birds } \\
\text { included in the Red Book of the Trans-Baikal Territory has been } \\
\text { registered, rare and protected species of mammals have not been } \\
\text { registered. }\end{array}$ \\
\hline Noise impact & $\begin{array}{l}\text { As a result of noise exposure, the death of animals is not predicted, } \\
\text { but a number of species will lose part of their habitats. In particular, } \\
\text { as a result of the noise, ungulates and large predators in the adjacent } \\
\text { floodplain of the river Lower Ingamakit. After the completion of the } \\
\text { stage, a slight increase in the number of some game animals is } \\
\text { possible (white hare, squirrel, sable, brown bear, hazel grouse, } \\
\text { ptarmigan, wood grouse), however, in most species the number will } \\
\text { not reach the initial level }\end{array}$ \\
\hline $\begin{array}{l}\text { Air pollution, etc. } \\
\text { and related indirect } \\
\text { impacts on the } \\
\text { habitats of certain } \\
\text { species of flora and } \\
\text { fauna, potentially - } \\
\text { the population }\end{array}$ & $\begin{array}{l}\text { Taking into account the geomorphological and landscape features of } \\
\text { the area where the mining and metallurgical facilities are located } \\
\text { (eluvial landscapes), the formation of geochemical anomalies } \\
\text { associated with the aerogenic influx of pollutants is not predicted } \\
\text { The risk of negative impact on the population and personnel is } \\
\text { minimized by the adoption of technological and planning decisions } \\
\text { on the organization of the sanitary protection zone of the MMP } \\
\text { Udokan }\end{array}$ \\
\hline
\end{tabular}

Thus, violations of natural complexes during copper mining are inevitable; design solutions are aimed at minimizing this harm. The main destructive changes will occur during the construction phase of the mining and metallurgical complex. They are characterized, among other things, by the loss of natural complexes, which leads to a decrease in biodiversity, the loss of valuable and rare species, and a decrease in the ecosystem functions of landscapes. Thus, the impact of the construction and the Udokan project on copper mining is assessed as significant. However, taking into account the observance of all technical and operational standards, it can be assessed as acceptable. The planned activity involves the phased development of the licensed area. The commissioning of new sites is accompanied by the development and reclamation of previously operated sites

The prepared project documentation received positive conclusions of state examinations (FGU "GlavGosExpertisa of Russia" and RosPrirodNadzor) .

\subsection{Monitoring}

In accordance with Federal Law No. 7-FL dated January 10, 2002 "On environmental protection", the organization of monitoring of the company's impact on the environment is an obligatory component of environmental protection measures.

From 2012 to the present, INREC SB RAS has been carrying out monitoring observations within the framework of the "Program for monitoring the state of the environment on the territory of the Udokanskoye field in the Kalarsky district" agreed on 
10/20/2011 by the Subsoil Use Office for the Trans-Baikal Territory (with agreed amendments dated 03.12.2013 . and taken into consideration the amendments of 02.05.2017 and adjustments for the construction period in 2018).

The basis for the development and implementation of the environmental monitoring program at the Udokan copper deposit, in addition to the extensive scientific material accumulated by the Institute in previous years, was the results of engineering and environmental surveys carried out by INREC SB RAS in 2011 at the request of SRK Consulting (Russia) Ltd, which prepared volumes of design documentation for Baikal Mining Company (BMC) LLC. As part of the research, the Institute examined the flora and fauna, geomorphological, landscape, hydrological structure of the territory, the ecological state of the soil cover, ground and surface waters, and socio-economic conditions [4-8].

Based on the analysis of the materials of complex studies and in accordance with the Federal Law of the Russian Federation No. 7-FL dated January 10, 2002 "On environmental protection" as amended on June 26, 2007, the Institute developed a program for environmental monitoring of the state of the environment in the region development of the Udokan copper deposit.

The program was developed in two stages of work:

1. Stage of geological and economic work, technological work and design for the Udokan field.

2. Stage of construction and operation.

The first stage lasted from 2012 to 2018 on the basis of the Program for environmental monitoring on the territory of the Udokanskoye deposit in the Kalarsky district of the Zabaikalsky Territory, agreed on October 20, 2011 by the Subsoil Use Administration for the Trans-Baikal Territory (with Amendment No. 1 dated December 03, 2013, Amendment No. 2 dated 05/02/2017). Considering that the work at this stage was not associated with a large-scale violation of the environment, the monitoring program included the minimum necessary set of monitoring activities, which makes it possible to quickly and qualitatively assess the impact of current activities on natural complexes. At the same time, the program generally recommended the types of additional work that should be carried out at the stage of construction and operation, subsequently the recommendatory section formed the basis for developing the program for the next stage.

At the first stage of work, the greatest risks were associated with the possibility of contamination of the watercourses of the territory during drilling operations (the flow of drilling mud, suspended solids, oil products, etc.). In this regard, the greatest attention was paid to monitoring the state of natural waters.

Monitoring of flora and fauna was deemed inappropriate and uninformative without a clear understanding of the proposed infrastructure and location of the enterprise's facilities, therefore, at this stage, these studies were not carried out.

At the first stage of work, the environmental monitoring program included the following sections:

- Control of the quality of atmospheric air.

- Monitoring of the radiation situation in core storage facilities.

- Monitoring of the hydrochemical state of natural waters.

- Monitoring of aquatic biological resources (zoobenthos, zooplankton).

- Monitoring of the state of the soil cover.

In general, according to the first stage of environmental monitoring, it can be concluded that the impact of the activities of BMC LLC on the components of the natural environment was minimal and did not lead to any irreversible negative transformations. Not a small role in this, in addition to the environmentally responsible attitude of the company to the methods of work, was played by the fact that environmental monitoring was carried out by an independent organization (INREC SB RAS) regularly notifying the Customer about the 
state of affairs in the field of work (including those carried out by contractors ).

The second stage of environmental monitoring began in 2019 and continues to this day.

The program of the second stage is an extended version of the program that has been operating at the field since 2012. When the enterprise enters the construction stage, the pressure on the environment will significantly increase. In this regard, it was necessary to introduce additional components of the natural environment into monitoring.

At the second stage of work, the environmental monitoring program included the following sections:

- Control of the quality of atmospheric air.

- Monitoring of the radiation situation.

- Monitoring of the hydrochemical state of natural waters.

- Monitoring of the hydrochemical state of water in water intake facilities and water supply systems.

- Monitoring of aquatic biological resources (zoobenthos, zooplankton).

- Monitoring of fish fauna.

- Monitoring of the state of the soil cover.

- Monitoring of plant communities.

- Monitoring of terrestrial mammals.

- Monitoring of avifauna.

- Monitoring of terrestrial invertebrates.

- Monitoring of noise impact.

In addition, in 2019, within the framework of monitoring studies, a paleontological survey of the territory was carried out.

It is too early to draw conclusions on the second stage at the moment, however, according to the results of monitoring work for 2019-2020, no significant violations that could cause severe environmental consequences were identified. Local disturbances of natural complexes during construction work were identified strictly within the boundaries of the allotment. There are no unregulated landfills, road tracks, etc.

\subsection{Environmental activities}

The complex of environmental protection measures proposed in the documents for environmental engineering surveys and EIA is being implemented in stages with the support of the company. So in 2019, as compensation measures, work was carried out to survey the territory and prepare materials for the ecological and economic feasibility study of the Ingamakitsky natural landscape reserve in the Kalarsky district on an area of 43.3 thousand hectares. The nature conservation value of this protected area lies in the preservation of a valuable natural area, places of high concentration and stable numbers of hunting and commercial species of animals (elk, red deer, musk deer, sable, Siberian weasel, lynx, squirrel, white hare, wood grouse), enrichment with valuable commercial species of adjacent territories.

As a result of engineering and environmental surveys at the site of the Udokan MMP facilities, the growing areas of a protected species included in the Red Data Book of the Trans-Baikal Territory - golden rhododendron (Rhododendron aureum Georgi) were identified. In 2019 and 2020, two stages of transplantation (translocation) of this species were carried out as a method of habitat restoration and preservation of the population of rare species in the subalpine mountain landscapes of Siberia. The assessment showed a high survival rate of the species, which allows further use of the developed methodology for inclusion in the reclamation project. 


\section{Conclusion}

Thus, the specialists of the Institute carry out a comprehensive step-by-step support of the construction project for the MMP Udokan at all key stages. The general goal of environmental management is to prevent environmental degradation and ensure the environmental safety of the project. Comprehensive long-term research is a significant advantage in terms of the availability of long-term research data, our own field surveys, which allow to reliably assess the course and scale of changes in natural environments, to give professional recommendations, which ultimately allows minimizing the negative impact of the construction of one of the largest mining facilities in Russia.

\section{References}

1. A.B. Ptitsyn, L.V. Zamana et al, Udokan: geology, ore formation, conditions of development (Nauka, Novosibirsk, 2003)

2. V.A. Abramova, A.V. Parshin, A.E. Budyak, A.B. Ptitsyn, J. Min. Sci. 53, 501-597 (2017) DOI: 10.1134/S1062739117032559

3. B.I. Gongalsky, Deposits of a unique metallogenic province Northern Transbaikalia (VIMS Publishing Casam, Moscow, 2015)

4. T. Harter, Watersheds, Groundwater and Drinking Water: A Practical Guide (UCANR Publications, 2008) ISBN 9781879906815

5. A. Kot-Wasik, J. Namieśnik, Soil and Water Pollution Monitoring, Protection and Remediation (Springer Science+Business Media, 2007) ISBN 9781402047282

6. C.M. Aelion, Environmental Monitoring (EOLSS Publications, 2009) ISBN 9781905839766

7. United Nations Environment Programme. Mineral Resources Forum. General guideline for an environmental monitoring programme

8. V. Sladecek, Hydrobiologia 100 (1983) 